\title{
Green Marketing, Ecolabel and Purchase Intention on Food Products during Covid-19
}

\author{
Nariman Aulia ${ }^{* 1,}$ Janti Gunawan ${ }^{* 2}$, Muniroh Sumarsono ${ }^{* 3}$ \\ Department of Business Management, Institut Teknologi Sepuluh Nopember, Surabaya 60111, Indonesia \\ ${ }^{*}$ Corresponding authors. Email: nariman16@mhs.mb.its.ac.id; \\ janti_g@mb.its.ac.id; \\ munirohsumarsono@gmail.com
}

\begin{abstract}
The Covid-19 Pandemy has increased consumer's awareness of the health issues and what they eat on a daily basis. Within the fast-moving consumer goods (FMCG) category, ecolabel is used to differentiate environmental friendly food and conventional food. However, not all of the healthy products are having ecolabel. This might happened because consumers do not know about the product, the price does not fit with their budget, the promotion does not reach the consumers and many other reasons. During the Covid-19 Pandemy, food manufacturing companies may need to adjust the massage to meet their targetted market. Therefore, this study examines how green marketing, ecolabel and Covid-19 pandemic relate to consumer's purchase intention of food products. What aspects are they considering? An online survey was conducted in May - June 2020, involving 349 valid respondents, from 34 provinces in Indonesia. This study found that green marketing mix is positively associated with consumer attitude. Interestingly, only green products and green promotion are positively associated with the green marketing mix. Green price and green place are not significantly related to the green marketing mix. Furthermore, ecolabel and Covid-19 pandemic are positively associated with consumers'attitude. This consumers attitude is then positively associated with green food products' buying intention. The findings of this study imply the need for food producers to allocate attention to food labelling, through good products and promotion. As of Covid-19 pandemic, this study found that the respondents will continue their healthy habit to protect themselves against health issue in the future. This offers positive signals to producers and marketing communication to develop a better communication approach for consumers.
\end{abstract}

Keywords: Covid-19, Ecolabel, Green Marketing Mix, Purchase intention.

\section{INTRODUCTION}

Fast Moving Consumer Goods (FMCG) are products that relate closely to consumers. They include homecare, personal care, foods and beverages [1]. Kantar [2] reports that foods and beverages contribute most to FMCG transactions. The number of FMCG manufacturers grow up to $6 \%$ annually [3], which indicate a positive economic development, however, these FMCG companies growth also result in the increasing pollution of their packaging. Green issues, such as green products, ecolabel, and greenways of doing business are proposed to balance the economic growth of the FMCG sector while also protecting the environment.

Ministry of Industry [4] reports that food and beverage (F\&B) manufacture are the subsector that contributes significantly to the Indonesia economy (almost 35\% of the GDP comes from F\&B subsector in 2018). In 2019, Covid- 19 pandemic has started in China, and it reaches Indonesia in March 2020. [5] This pandemic has resulted in the increased attention of healthy lifestyles, such as through food consumption. The sales of products with an ecolabel is believed to be in demand. However, Kantar [2] reports that out of the top ten Indonesia consumer products, seven of them are F\&B products but only two of them have ecolabelling. Therefore, a studythat 


\section{Procedia Business and Financial Technology}

Proceedings of the 2nd International Conference on Business and M anagement of T echnology (ICO N BM T 2020) - Part 2

investigates how green marketing, ecolabel and purchase intention on food products during Covid-19 pandemic is needed. The objectives of this study are two folds. Firstly, to identify the relationship between green marketing mix and ecolabel to consumer attitude and their intention to buy. Secondly, to identify the characters of green products consumers. The results of this study may provide a better understanding of consumer attitude in buying green products, which is valuable to both academics, manufacturers and environmental bodies.

\section{LITERATURE REVIEW}

\subsection{FMCG, Green FMCG and Ecolabel}

Morel \& Kwakye [6] define Fast Moving Consumer Goods (FMCG) as products that are fastly transacted, with low cost of a transaction. Green FMCG is a subsector of that focuses on recycling, reducing the impact of their product waste and package, to minimise the negative impact on the environment. The marketing of this green FMCG is called Green Marketing Mix.

There are four aspects of the green marketing mix. They are: green product, green price, green place and green promotion [7].Green products stress the concern that the products are not harmful to humans and the environment, have minimal impact on the environment, do not produce excessive waste, are economical in resources, and do not involve cruelty to animals [8]. Green price stresses that the price set by a company consider environmental value. Green Place concern on the most effective location determined by the company to sell and distribute products to prospective buyers without damaging the environment. Green Promotion includes environmental sustainability [9]. These Green FMCG has been researched widely in the developed countries, such as Sweden as the former research by Morel and Kwakye but limited is known about Indonesia FMCG.

Within the FMCG groups in Indonesia, food and beverage dominate their transactions [2], and the $\mathrm{F} \& \mathrm{~B}$ green products are reflected in their eco-labelling. Ecolabel is a reflection of the company concern of the environmental values, which is shown in their products, process and commitments. This ecolabel is issued by an independent institution. However, up to July 2015, only 200 Indonesian products that comply with institutional ecolabelling [10]. This reflects only less than $1 \%$ of Indonesia F\&B has institutional ecolabel, and stress the need for a study in the area of ecolabel in Indonesia.

\subsection{Consumer's attitude, environmental issue and their buying intention}

The consumer is unique. In the marketing field, it is necessary to understand consumer's attitude, an expression of consumer's perception about the product [11]. Studies found that the consumer's attitude is associated with their knowledge. With regards to the $85 / 180$ green product, it relates to the information they $\mathrm{read} / \mathrm{received}$, such as in the ecolabel.

On the other hand, consumers may also learn or obtain knowledge from public sources. Awareness-raising frequently promotes environmental issues, including public health and or long term public concern [12]. In this pandemic Covid-19 period, the government constantly promote public awareness of health issues.

In the area of marketing, consumer's knowledge and attitude are measured in their intention to buy. The green intention to buy is a tendency to buy product or service that has considered environmental values [13].

Combining all the above, this study reflects the previous study in the following model:

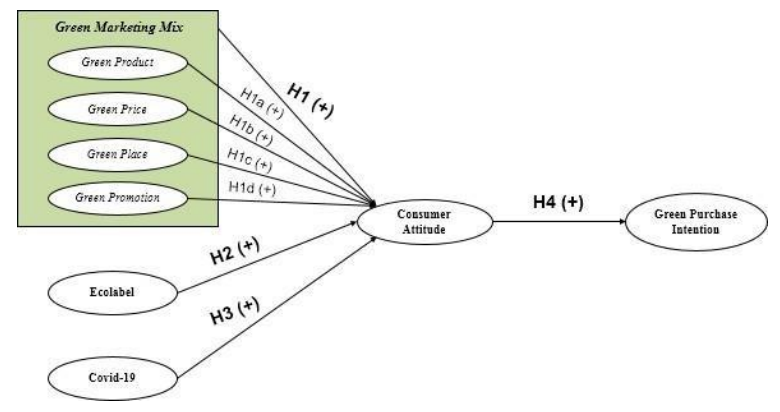

There are four hypotheses of this study:

H1: Green marketing mix is positively associated with consumer attitude attitude toward green $\mathrm{F} \& \mathrm{~B}$ $\mathrm{H} 2$ : Ecolabel is positively associted with consumer attitude attitude toward green $\mathrm{F} \& \mathrm{~B}$

H3: Awarenss of Covid-19 is associated with consumer attitude toward green $\mathrm{F} \& \mathrm{~B}$

$\mathrm{H} 4$ : Consumer attitude toward green product is positively associated with their intention to buy green F\&B.

\section{METHODOLOGY}

An online survey was conducted in May - June 2020, responded by 363 respondents through an online survey. The number meet minimum requirements for Structural Equation Modelling of this study (29 variables x 10). The respondents are $\mathrm{F} \& \mathrm{~B}$ consumers in Indonesia, who consumed green $\mathrm{F} \& \mathrm{~B}$ products in the last three months before data collection. There are four variables of this study: green purchase intention variables are measured by four indicators that range from consumer's interest, plan to buy, want to buy and try to buy [2] [11], the green marketing mix variables are measured by twelve indicators [14], that cover green products, green price, green place and green promotion; the ecolabel variable is 


\section{Procedia Business and Financial Technology}

Proceedings of the 2nd International Conference on Business and M anagement of T echnology (ICO N BM T 2020) - Part 2

measured using five indicators developed [15], [16], the influence of environmental issues is measured by indicators developed by [17] and the questions are adjusted to fit with Covid-19 pandemic context. The consumer attitudes variable is measured by four indicators developed by [2] [6]. Each question is using a 5 level scale, and the variable is measured by averaging the responses on each indicator, to maintain the consistent meaning of each variable in this study. Outlier test, normality test and linearity tests were conducted to ensure that only valid and clean data are used for analysis. Each variables has minimum reliability score(Cronbach alpha $>0,7)$ [18], which indicate reliable measures.

\section{FINDINGS and DISCUSSION}

The table below summarises Structural Equation Modelling Analysis.

Table 4.1. Summary of Hypotheses testing

\begin{tabular}{|c|c|c|c|c|c|c|}
\hline $\begin{array}{c}\text { Hypot } \\
\text { hesis }\end{array}$ & \multicolumn{3}{|c|}{ Variable relationship } & Std. & $\begin{array}{c}\text { P- } \\
\text { value }\end{array}$ & $\begin{array}{l}\text { Re } \\
\text { mar }\end{array}$ \\
\hline H1 & $\begin{array}{c}\text { Green } \\
\text { Marketing } \\
\text { Mix }\end{array}$ & $\overrightarrow{(+)}$ & $\begin{array}{l}\text { Consumer } \\
\text { Attitude }\end{array}$ & 0,58 & $* * *$ & $\begin{array}{l}\text { Acc } \\
\text { epte } \\
\text { d }\end{array}$ \\
\hline H1A & $\begin{array}{c}\text { Green } \\
\text { Product }\end{array}$ & $\overrightarrow{(+)}$ & $\begin{array}{c}\text { Green } \\
\text { Marketing } \\
\text { Mix }\end{array}$ & 0,60 & $* * *$ & $\begin{array}{l}\text { Acc } \\
\text { epte } \\
\text { d }\end{array}$ \\
\hline H1B & $\begin{array}{l}\text { Gree } \\
\mathrm{n} \\
\text { Price }\end{array}$ & $\overrightarrow{(+)}$ & $\begin{array}{c}\text { Green } \\
\text { Marketing } \\
\text { Mix }\end{array}$ & 0,43 & 0,217 & $\begin{array}{l}\text { Reje } \\
\text { cted }\end{array}$ \\
\hline $\mathrm{H} 1 \mathrm{C}$ & $\begin{array}{l}\text { Gree } \\
n \\
\text { Place }\end{array}$ & $\overrightarrow{(+)}$ & $\begin{array}{c}\text { Green } \\
\text { Marketing } \\
\text { Mix }\end{array}$ & 0,22 & 0,448 & $\begin{array}{l}\text { Reje } \\
\text { cted }\end{array}$ \\
\hline H1D & $\begin{array}{c}\text { Green } \\
\text { Promotion }\end{array}$ & $\overrightarrow{(+)}$ & $\begin{array}{c}\text { Green } \\
\text { Marketing } \\
\text { Mix }\end{array}$ & 0,49 & 0,012 & $\begin{array}{l}\text { Acc } \\
\text { epte } \\
\text { d }\end{array}$ \\
\hline $\mathrm{H} 2$ & Ecolabel & $\overrightarrow{(+)}$ & $\begin{array}{l}\text { Consumer } \\
\text { Attitude }\end{array}$ & 0,17 & 0,011 & $\begin{array}{l}\text { Acc } \\
\text { epte } \\
\text { d }\end{array}$ \\
\hline $\mathrm{H} 3$ & $\begin{array}{l}\text { Covid-19 } \\
\text { Pandemic }\end{array}$ & $\overrightarrow{(+)}$ & $\begin{array}{l}\text { Consumer } \\
\text { Attitude }\end{array}$ & 0,21 & 0,004 & $\begin{array}{l}\text { Acc } \\
\text { epte } \\
d\end{array}$ \\
\hline $\mathrm{H} 4$ & $\begin{array}{l}\text { Consumer } \\
\text { Attitude }\end{array}$ & $\overrightarrow{(+)}$ & $\begin{array}{c}\text { Green } \\
\text { Purchase } \\
\text { Intention }\end{array}$ & 0,78 & $* * *$ & $\begin{array}{l}\text { Acc } \\
\text { epte } \\
\text { d }\end{array}$ \\
\hline
\end{tabular}

$* * *:<0,001$
This study has four hypotheses. H1, H2, H3 and H4 are accepted. H1 has four sub hypothesis, two of them are accepted and two others are rejected. In general, the marketing mix is positively associated with the consumer's attitude. Within the marketing mix dimension, only green products and green promotion matter. Green price and green place are not significantly related to the green marketing mix. Furthermore, ecolabel and the consumer's knowledge about Pandemy Covid-19 is positively associated with consumer behaviour, which further result in consumer purchase intention.

The study confirms that green purchase intention is influenced by green consumer attitude, which is influenced by the three variables: Green marketing mix, ecolabel and consumer's awareness of Covid-19 pandemic issue. Out of these three variables, the green marketing mix is having highest influence to consumer's attitude (with significant relationship coefficient 0,59), followed by the knowledge about Covid-19 issue on health (relationship coefficient 0,21) and ecolabel (relationship coefficient 0,19 ). This means that F\&B manufacturers need to put attention on their marketing mix, especially the green products and green promotion. This study was responded mainly by female consumers $(65 \%)$, university graduate $(52 \%)$, age $18-25$ years $(46 \%)$, with income less than IDR 2 million (33\%). These findings indicate that the green attitude and intention to buy green products do not necessarily come from highincome earners, but the marketing mix, ecolabel and consumer's awareness. Indeed, the respondents of this study said that they will continue healthy living habit when the Covid-19 pandemic ends. In average, the respondents earn IDR 1337000 per month, and 35\% of them allocate budget for $\mathrm{F} \& \mathrm{~B}$ around $21-40 \%$, with the average value of the transaction between IDR $50000-$ IDR 250000 . Most of them read ecolabel and buy offline to get green products. This finding consistent when cross tab analysis was conducted against a different level of income and different level of education. The findings offer potentials for green products to expand their (offline) market and reaching wider consumers.

\section{CONCLUSION}

This study aims to identify the relationship between green marketing mix and ecolabel to consumer attitude and their intention to buy. The study confirms that green marketing mix and ecolabel is positively associated with consumer attitude and their intention to buy.

The second objective of this study is to identify the characters of green products consumers. Through a survey of 363 respondents from 34 provinces, this study

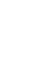

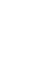




\section{Procedia Business and Financial Technology}

Proceedings of the 2nd International Conference on Business and M anagement of T echnology (ICO N BM T 2020) - Part 2

confirms that green consumers are mainly female, either university students or graduate. Their income are less than 2 million, and spend up to $40 \%$ of their income on food. With the young age of these consumers and their awareness of health issue, the green food manufacturers should build the consumer's knowledge and build the relationship. This group of consumer awareness of a healthy lifestyle, as they are mainly read ecolabel.

The Covid-19 pandemic confirms that consumers aware of their health and agree to buy green products to secure their health. Interestingly, they said that they will continue a healthy lifestyle after the Covid-19 pandemic. Therefore, manufactures are suggested to develop customer relationship, such as through ecolabel as their communication channel, and regular online seminars on the area where the consumer can find their products. By doing so, consumers believe that green manufacturer care of their health and may willing to spend more of their disposable income to buy green products.

This study was conducted during Covid-19 pandemic, on one hand, it offers opportunities for green products, and online platform. However, this study found that most of the consumers are still buying green products offline. It may call for further analysis and exploration of the green consumer to buy online and understanding better channel of distribution.

Although this study has responded by representatives from 34 provinces, $57 \%$ of them come from East Java province. Further study may conduct an online survey to have an equal proportion of the sample. But this may also indicate that the green products are not available in the other areas of Indonesia. Such situation offer market potential for green products manufacturers.

\section{ACKNOWLEDGMENT}

This work was supported by the Department of Business Management, Faculty of Creative Design and Digital Business, Institut Teknologi Sepuluh Nopember, Surabaya, Indonesia. (60111)

\section{REFERENCES}

[1] Nijssen, E. J. (1999). Success factors of line extensions of fast-moving consumer goods. European Journal of Marketing, 33(5/6), 450-474. https://doi.org/10.1108/03090569910262044

[2] Kantar. (2019). Brand Foodprint: Indonesia's Ranking of The Most Chosen Brands 2019.

[3] Greenpeace Indonesia. (2018). The Global Survey Reveals the Contribution of FMCG Companies to the Future of Plastic Pollution Crisis. Retrieved from https://www.greenpeace.org/indonesia/siaranpers/1749/survei-global-mengungkap-kontribusi- perusahaan-fmcg-terhadap-krisis-polusi-plastik-dimasa-depan/

[4] Kemenperin. (2017). Food and Beverage Industry is Still a Mainstay. Retrieved from https://kemenperin.go.id/artikel/18465/Industri-

Makanan-dan-Minuman-Masih-Jadi-Andalan

[5] Pusat Kritis Kesehatan. (2020). COVID-19 Indonesia infographic,March 23, 2020, 08:00 WIB. Retrieved March 23, 2020, from Kementrian Kesehatan Republik Indonesia website: http://www.pusatkrisis.kemkes.go.id/infografiscovid- 19-indonesia-23-maret-2020-0800-wib

[6] Morel, M., \& Kwakye, F. (2012). Green marketing : Consumers ' Attitudes towards Eco-friendly Products and Purchase Intention in the Fast Moving Consumer Goods ( FMCG ) sector. Umea Universitet.

[7] Kotler, P., \& Armstrong, G. (2008). Principle of Marketing (12th ed.; J. Shelstad, Ed.). Pearson.

[8] Febriani, S. (2019). The Effect of Green Marketing Mix on Green Product Purchase Intention on Innisfree Products in Jakarta with Consumer's Attitude as Mediation Variable.Jurnal Manajemen Bisnis Dan Kewirausahaan, 03(No.1), 49-60.

[9] Ansar, N. (2013). Impact of green marketing on consumer purchase intention. Mediterranean Journal of Social Sciences, 4(11), 650-655. https://doi.org/10.5901/mjss.2013.v4n11p650

[10] Prasetyo, B. (2015). Currently, there are only 200 products in Indonesia that are FSC Certified. Retrieved March 9, 2020, from https://www.tribunnews.com/bisnis/2015/07/09/saa t- ini-baru-ada-200-produk-di-indonesia-yangbersertifikat-fsc

[11] Basumbul. (2016). Consumer' Attitudes In Mediating The Influence Of Green marketing On The Purchase Intention. (Universitas Bandar Lampung). https://doi.org/10.5151/cidi2017-060

[12] Kusuma, Y., Abdul, H., \& Pudji, P. (2018). The Effect of Environmental Knowledge, Green Advertising and Environmental Attitude Toward Green Purchase Intention. Russian Journal of Agricultural and Socio- Economic Sciences, 6(June), 496-504.

[13] Dewi, R., Puspaningrum, A., \& Hadiwidjojo, D. (2019). The Interaction of Green Perceived Value, Green Brand Image, and Green Trust to Green Purchase Intention. 15(1), 1-16.

[14] Athanasius, S., Hung, W., Ho, S., \& Sitohang, P.

S. (2015). Influence of Green Marketing toward Purchase Intention of Green Products through Attitude: Survey on Indonesian and Taiwanese Students. International Journal of Humanities and Management Sciences, 3(4), 198-202

[15] Song, Y., Qin, Z., \& Yuan, Q. (2019). The impact of eco-label on the young Chinese generation: The 


\section{Procedia Business and Financial Technology \\ Proceedings of the 2nd International Conference on Business and M anagement of T echnology (ICON BM T 2020) - Part 2}

mediation role of environmental awareness and product attributes in the green purchase. Sustainability (Switzerland), 11(4). https://doi.org/10.3390/su11040973

[16] Cai, Z., Xie, Y., \& Aguilar, F. X. (2017). Eco-label credibility and retailer effects on green product purchasing intentions. Forest Policy and Economics, 80, 200-208. http://doi.org/10.1016/j.forpol.2017.04.001
[17] Tanaya, D., \& Rastini, N. (2016). The Role of Concern in the Environment Mediates Environmental Knowledge of Green Product Purchase Intentions. E- Journal Management Universitas Udayana, 5(6), 245360.

[18] Maholtra. (2010). Marketing Research (6th ed.). Pearson Prentice Hall.
$88 / 180$ 